\title{
S49. Clinical activity and development of biomarkers for an engineered anti PDL1 antibody MPDL3280A
}

E Cha

From 1st Immunotherapy of Cancer Conference (ITOC1)

Munich, Germany. 12-14 March 2014

\section{Background}

Human cancer cells may suppress the adaptive immune response by expressing $\mathrm{PD}-\mathrm{L} 1$ and down-regulating T cell activity through PD-L1/PD-1 and PD-L1/B7.1 interactions. Disruption of PD-L1 signaling restores antitumor immunity, resulting in durable responses across multiple human tumor types. Here we describe the clinical activity and development of predictive biomarkers for MPDL3280A, a human monoclonal antibody with an engineered Fc-domain designed to optimize safety and efficacy, that targets PD-L1 and prevents binding to receptors $\mathrm{PD}-1$ and $\mathrm{B} 7.1$.

\section{Materials \& methods}

We evaluated a multitude of biomarkers from pretreatment tumor specimens collected during clinical study of MPDL3280A. MPDL3280A has been administered as a monotherapy in over 300 pts with locally advanced or metastatic solid tumors in a phase 1 study.

\section{Results}

To date, MPDL3280A has been well tolerated across multiple dose levels and no G3-5 pneumonitis has been reported. Responses were observed in multiple tumor types, including NSCLC, RCC, and melanoma, with ongoing responses seen in the majority of responders. We report the association between pretreatment immune-related markers and response to MPDL3280A.

\section{Conclusion}

Overall, our assessment of tumor specimens not only has resulted in markers that may potentially identify response to MPDL3280A but also has furthered our

Genentech, South San Francisco, CA 94080, USA understanding of the biologic activity of PD-L1 inhibition on treatment.

Published: 12 March 2014

doi:10.1186/2051-1426-2-S2-121

Cite this article as: Cha: S49. Clinical activity and development of biomarkers for an engineered anti PDL1 antibody MPDL3280A. Journal for ImmunoTherapy of Cancer 2014 2(Suppl 2):121.
Submit your next manuscript to BioMed Central and take full advantage of:

- Convenient online submission

- Thorough peer review

- No space constraints or color figure charges

- Immediate publication on acceptance

- Inclusion in PubMed, CAS, Scopus and Google Scholar

- Research which is freely available for redistribution
C Biomed Central

\section{Biomed Central}

